\title{
Narrative Patterns in Indonesian Fine Art
}

\author{
Acep Iwan Saidi ${ }^{1}$, Dyah Gayatri Puspitasari ${ }^{2}$, Ferry Fauzi Hermawan ${ }^{3}$ \\ ${ }^{1}$ Faculty of Arts and Design, Institut Teknologi Bandung, Indonesia \\ 2Visual Communication Design, Binus University, Indonesia \\ 3Institut Teknologi Bandung, Indonesia \\ Email: acepiwans@fsrd.itb.ac.id
}

\begin{abstract}
This paper aims to describe the structure and pattern of narratives in art, which in this case Indonesian fine art is used as a case study. This topic is important considering that the assumption that works of fine art have narrative characteristics has become common knowledge, but the structure and narrative patterns within the genre of work of fine art that can be used as a reference have not yet been formulated. By using a structural semiotic approach, studies in this paper have found that narrative patterns in fine art are a combination of denotative visual sign units presented as works on the syntagmatic axis of language (visual) interrelated to form associations or groups of narrative connotations on the paradigmatic axis (community knowledge system). This proposition, as well as several other formulations found in the analysis, has a significant contribution to the development of fine art, both theoretically and practically, both in Indonesia and the world.
\end{abstract}

Keywords: narrative, syntagmatic, paradigmatic, denotation, connotation, collective expression

\section{Introduction}

To put it simply, narration can be defined as a set of events. Genette (1987:25) said, "narrative refers to the succession of events, real or fictitious, that are the subjects of this discourse, and to their several relations of linking, opposition, repetition, etc". Based on this opinion, the essence of human life is narration. That is because human life consists of following events: in relationships, opposition, repetitive patterns, and so on. Human life stops when the event (narration) has ceased to exist.

In such narrative reality, human beings are the doers of events, whereas the place and time of the event are the setting and how the sequence of events is arranged is the plot. All of this happens naturally as the reality of human experience in his life. Then, because humans are creatures of language or in classical Greek philosophy called animals of storytelling, a series of events in human life is always articulated through language.

Therefore, as one refers to another Genette's record in the same book, narration can be interpreted as a retelling of something. According to Genette (1987), "narrative refers once more to event: not, however, the event that is recounted, but the event that consists of someone recounting something: the act of narrating taken itself. Gennete also wrote, "Narrative refers to the narrative statement, the oral or written discourse that undertakes to tell of an event or a series of events". A story is known in such a way. Therefore, a story is a narrative that is told, both oral and written. In the oral tradition, various tales about events related to humans and the things they witness (natural events, animals, etc.) are retellations of narratives or sequences of events in the reality of experience. With that in mind, it cannot necessarily be considered as a fiction. As said by Junus (1981), in his day what is now called a myth is also reality. This confirms that mythological tales are a retelling of reality. 
Such historical cultural facts seem to set their strong characteristics in Indonesian fine art. From era to era, since prehistoric times until now, the narrative characteristic has almost never been lost in the works of Indonesian artists. odern Indonesian paintingis to show special signs from a field of science (Iswahyudi, 2020). When modern art (modernism) entered Indonesia through fine art teachers from Europe (the Netherlands), namely through the Image Teacher Education School at Bandung Institute of Technology in the 1950s to 1960s, abstract art (formalism) had indeed dominated. However, that only applies to the group of artists at the school. Instead of affecting the entire development of Indonesian fine art, at that time there was a debate related to the new style of fine art.

However, the dominant character of such narrative art, so far it is not yet clear as to the narrative patterns that shaped it. Supangkat (1996), curator and critic of Indonesian fine arts, identified that narrative fine art is a visual work (painting) in which stories are drawn with a crowd as their characteristics. The crowd in question is the number of objects drawn, which appears to be related to each other to form a story. Therefore, no longer acquire goods because of real needs but because of desires that are increasingly defined by commercials and commercialized images (Basirizadeh, 2020). An example can be seen in the painting titled "Gamelan Sunda" by Otto Djaya below (figure 1).

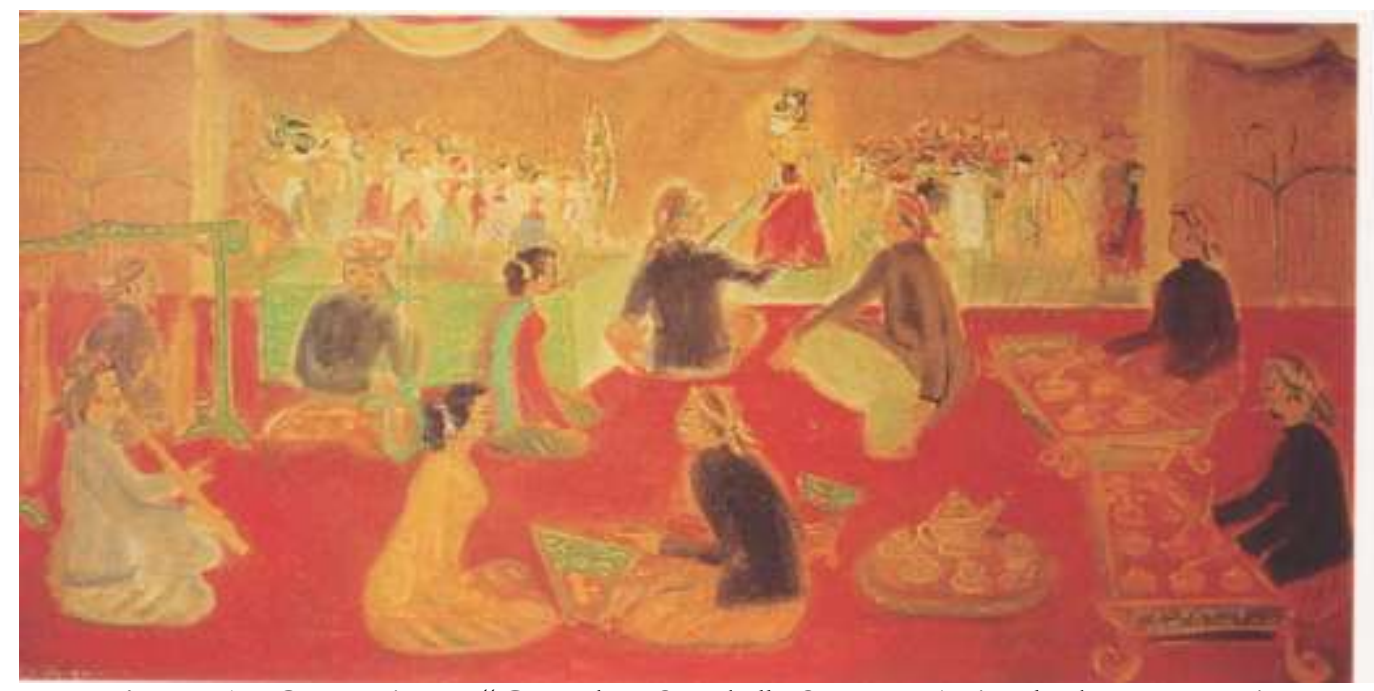

Figure 1. Otto Djaya, "Gamelan Sunda". Source: Writer's documentation

The painting shows human figures, Sundanese musical instruments (gamelan), puppet dolls, tables, and stage decoration fabrics are drawn in such a way that each other looks interconnected. The drawn figures give the impression of responding to each other, and other objects are also painted in such a way that they are related to each other in order to form a kind of event, in this case the event of a group of people playing a gamelan instrument. Paintings like this are identified by Supangkat as narrative or storytelling, in which there were many elements drawn, all of which seemed to form a story.

In our opinion, the identification of narrative characteristics in such works of fine art is inadequate. The word "crowd" has a meaning that is not clear or does not have a definition that can be referred to with certainty. Crowd is a loose term, with multiple interpretations, and thus considered relative. Therefore, we need a formula that is more likely to be referred to more stringently; at least it can be used as a standard reference. We have carried out research on this subject for the last twelve years or so. 


\section{Research Methods}

As stated in the previous section, works of fine art that have a tendency to tell stories or narratives are works that consist of picture elements that are interconnected to form a unity of messages and meanings. Based on this, works of fine art with these characteristics must be understood as a network or group of texts. The elements or objects that are interconnected in the picture are understood as textual language units that form a kind of sentence, paragraph, or composition in full. This means, the method that must be used is the method of text analysis.

Furthermore, semiotics which are the theoretical basis in the analysis of the visual narrative text above will refer to semiotics which are sourced from Saussure (1990) and Barthes (1985). Saussure's structural semiotics are used to identify the relationships of various visual sign elements in forming structures. In this case, the relevant theory of Saussure is its formulation of the relation between the syntagmatic and associative axis in language. The syntagmatic axis is the part that appears (in praesentia), which is nothing but a series of words in a sentence (syntax) or more broadly in a complete essay. The series of words will form an association in the reader's mind. Therefore, association is an aspect that is not present in the structure (in absentia). Associations are outside of language, which, according to Saussure, can substitute words and series of words that are present in the sentence structure or text. This syntagmatic-associative relational formula was further developed by Hjelmslev and Barthes (1985). For Hjemslev and then Barthes (1985), the term "association" changes to "paradigmatic" so that the relationship becomes one between syntagmatic-paradigmatic. Following is a chart of these relationships and their applications (figure 2).

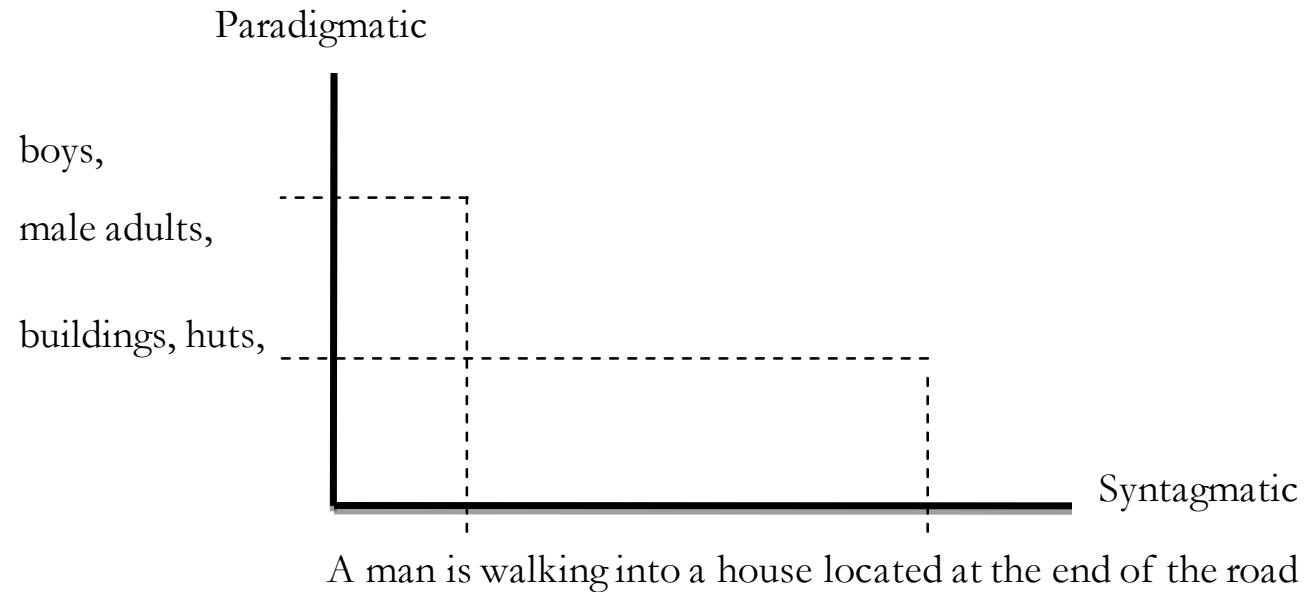

Figure 2. Chart of Syntagmatic-Paradigmatic Relations. Created by the writer with reference to Barthez (1985)

In the practice of visual narrative text analysis of visual works in this article, we place the artwork on the syntagmatic axis which is then correlated with the possibilities of the message and its meaning on the paradigmatic axis. This means that we do not practice the formula of Saussure or Barthes strictly.

Here in the paradigmatic realm is not always the aspect that strictly substitutes the elements contained in the syntagmatic axis as shown in the chart above. For example, the hut substitutes the house. Instead, the analysis of what is on the paradigmatic axis can be an association whose tendency is towards forming messages and meaning. We then combined 
and reinforced the basis of this method with Barthes's sign level theory. In semiotics, according to Barthes (1985), there are two levels of language signs, namely denotation and connotation.

Considering that this study focuses on the formulation of narrative patterns in fine art, we also integrate the construction of the semiotic methodology above with the general notions of narration that have so far been used in the realm of language and literature. In this realm narrative is seen as a story that consists of two layers, namely intrinsic and extrinsic layers. Intrinsic layers consist of events, figures and characterizations, settings, and plot. Beyond this, point of view, style, speech patterns, and metaphors are also important aspects of the intrinsic layer (Culler in Genette, 1995). In semiotics this aspect can be referred as language code. However, the most important aspect in the intrinsic layer is the event. There will be no stories if there are no events. Therefore, events are categorized as the core of the story. Events happen because of the presence of characters, which is why characters become an absolute condition for stories to occur even though they are not categorized as the core of the story. Of course, a story will take place if all the elements in this intrinsic layer are present and related to each other. At the extrinsic layer, a story is built on the thematic aspects. The theme is a basic idea in which there is also the message of the author's intention in writing the story. Speaking of an analogy to narration in visual works, understanding the aspects of the story above is useful to identify the extent to which these characteristics are present in vis ual works, in order to know whether they meet the requirements to be categorized as narrative works. However, of course, as will be seen in the analysis in the next section, the narrative pattern in fine art will not be exactly the same as the narration in literary works. Different genres, specific characteristics, and different media actually allow narratives in fine art to have their own patterns.

\section{Discussion}

Our research on narrative patterns in Indonesian fine art for the past twelve years uses selected data from the distribution of works in various eras, ranging from traditional to contemporary works. However, because there is so much data on the work, it is not possible to discuss all of them here. For the purposes of writing this article, our discussion will focus on several works of contemporary artists that already have an international reputation, namely Tisna Sanjaya, Heri Dono, Dede Eri Supria, and Agus Suwage. These four artists have listed themselves in the constellation of fine arts, both at the national and international levels, by holding various exhibitions, both exhibitions with other artists and solo exhibitions (Author, 2008). We will make the results of the analysis of their works later as a reference in identifying other works in the previous era, especially in the modern era, tradition, and even prehistoric times.

One main and important point in identifying narrative patterns in Indonesian fine art is the way Indonesian artists give titles to their works. For them, the title is the initial marker that guides the public appreciator into the semiotic events that are built into his work. In the artist Tisna Sanjaya, for example, the title is a mechanism about how events in everyday life are denoted (to denote) so that it is representative. In other words, the title becomes a mirror of events. Consider some of the titles chosen to name his work, including "Theater", "Feast of Thieves", "Eat Breakfast with Dogs", "Beat up Picasso", and most recently until this article was written, "Self-portrait as Hypocrites" (2019- 2020). All of these titles explicitly identify events. And events, as mentioned in the previous section, are the essence of the story. 
As an example of the case, one of the works above is analyzed, which is "Teater", a graphic work created by Tisna Sanjaya in the early period of his art? Teater, as a word, denotatively or according to the meaning of the dictionary is a drama performance (theater is a drama script that is staged). Placed on Saussure or Barthes' syntagmatic axis, theater can be dubbed by the dictates of "drama performances", "dance performances", and "musical operas". This title, as well as diction that can restore it to the paradigmatic axis, in addition to identifying events, also identifies characters (the players who move events), space (stage), time (duration of performances), and there is definitely a story told, both in the form of dialogue and narrative description. Now consider the following visuals entitled "Teater "(figure 3).

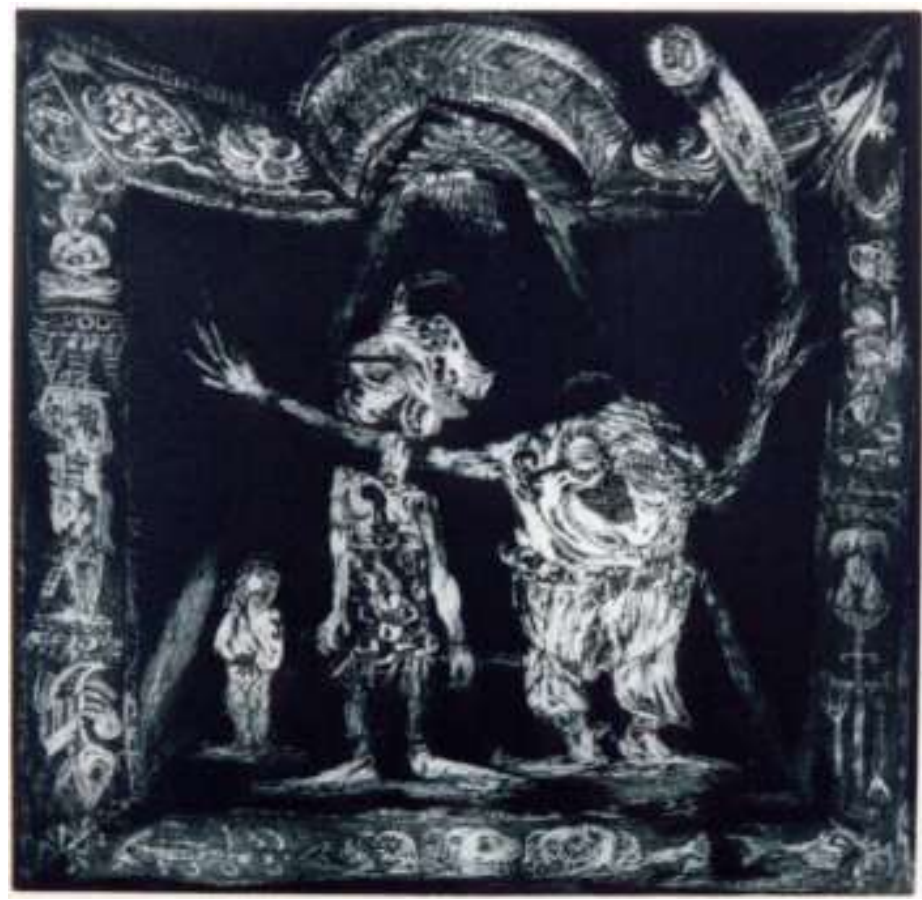

Figure 3. Tisna Sanjaya, "Teater" (1986), 33 x 33, etsa aquatin. Source: the writer's documentation

The visual that immediately stands out within the graphic work are the three figures of human posture, with an odd appearance, nonetheless. In the intrinsic layer, this strange appearance can be ignored. Here, in a theater context, what is important to see is the presence of these figures. The presence of the figure immediately shows its role as a character. This means that these figures fulfill the requirements of the narration. With the position arranged in such a way (blocking), the figures are picture elements that are related to each other to build certain atmosphere and messages. Therefore, the figures are the arrangement of visual sign units on the syntagmatic axis. The position of these figures appears to be a "diction" (unit of choice) that is not interchangeable. A large figure at the front with a gesture of two arms stretched upwards gives the impression of speaking, while the figure standing in the middle, with a raised shoulder gesture, a sideways glance shows more the attitude of the character who is listening. Finally, the smallest figure, standing at the back, shows a more attentive attitude to the dialogue of the first two figures.

How the artist placed the figures in such a way also indicatesa a drawing style (in the story can be read as a pattern said), namely perspective drawing style. The basis of this method of drawing is formal-rationality, that is, among other things, what appears to be far or distant is made small in the drawing, whereas those near are made larger in the drawing (Tabrani, 2005). However, in the context of the above work, what is far and small does not necessarily 
mean that they are not important. Instead, his presence is a condition for the occurrence of story events on the stage (room or setting). This also means that what is drawn and made bigger and located in front does not necessarily mean they are more important.

Furthermore, the narrative picture becomes even more pronounced when the visual elements on the syntagmatic axis are connected with their associations on the paradigmatic axis, that is, we connect the visual structure into reality (real system), an empirical event before the artist denotes it into an image. In addition to the diction of the theater as a title which has "led" the public to enter into the story as explained earlier, how the position of the figures are placed and the gestures that are displayed make it unlikely for us not to call it a scene of an event, which can therefore said that there is certainly is a story in it. On the paradigmatic axis, odd figures drawn can be exchanged with monsters, ghosts, and humans. Semiotically, the level of signs built through these figures is very connotative. And in Indonesian culture, such a figure can connote crime, greed, cruelty, and power. In Indonesian culture, evil and cruel power can be realized through the visualization of a scary or frightening human figure.

Furthermore, the narrative visualization model of Tisna Sanjaya above can also be identified in the works of Heri Dono. Like Tisna Sanjaya, the titles of Heri Dono's works are also titles that identify story events. Consider some examples, namely "Puppet Legend", "Watching Video", "The Bearer of the Peace Discuss", "The Capture of RM Soeharto", "Dialog dengan teman", and "Superman Baru Belajar Memakai Celana Dalam". Compared to Tisna Sanjaya's "Teater", these titles even more explicitly identify the story. If through the "teater" diction Tisna identifies the story indirectly (connotative), through the title "The capture RM Soeharto", for example, Heri Dono presents a picture of the story event directly (denotative). In other words, the title provides information about an event, namely the literal arrest of R.M Soeharto. Consider the visual form of the work below (figure 4):

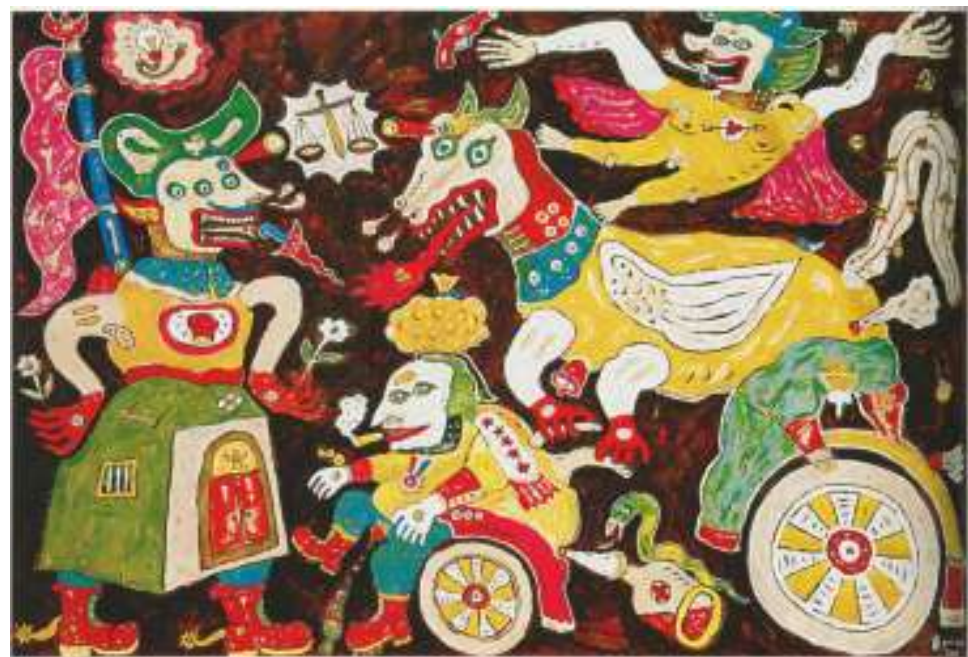

Figure 4. Heri Dono. "The capture of R.M Soeharto", (2003), $150 \mathrm{~cm} \times 200 \mathrm{~cm}$, mixed media on canvas. Source: the writer's documentation

Through the picture above, the narrative message of the events highlighted in the title can immediately be identified. Heri Dono fills his canvas with figures in the form of humans, animals and half-animal humans. The figure of a human who sits in a wheelchair and is in the middle of a crowd gives the impression of being surrounded. Connected by its title, this figure appears to be referred as R.M Suharto, the person arrested. Indonesians, especially those who lived between 1950-2000s, are familiar with this figure. Suharto was Indonesia's second president who ruled authoritatively for 32 years (1966-1998). In May 1998 Suharto was forced 
by the people to step down from his presidential throne. There were no arrests against him, but massive demonstrations carried out by students and other elements of society for several weeks at that time caused Suharto to surrender, thus no longer able to maintain his power.

In a chaotic socio-political situation, Suharto, who was already very weak in his power of attorney, was ultimately not only protested against by his students and political opponents, but also by those closest to him. The picture of the event that Heri Dono painted explicitly shows how each party, even the one who pushed his wheelchair, expressed anger (spitting fire from his mouth). The figure of the animal (horse) pushing the wheelchair, semiotically, can be interpreted as a militaristic vehicle which, during his rule is the mainstay of his power, while the human figure with the animal's head standing on his waist while spitting a dagger from his mouth can be interpreted as the military itself. Army boots, the green dress bottom, and a hat in the form of a green beret, at least, give the impression of such connotation.

The connotative impression or association on the paradigmatic axis, once again, can be quickly expressed because the real event that is denoted by Heri Dono through his work is a major event in the history of modern Indonesia. The "socio-political coup" or more popularly called reforms to remove Suharto from his presidency was the biggest political event after the September 30, 1965 movement that led to the downfall of Ir. Sukarno, Indonesia's first president, from his presidency. Heri Dono's works can thus be said to be visual works that explore semiotic signs on one side, but on the other hand send explicit messages like realist works.

Apart from this, an interesting aspect of Heri Dono's work lies in how this artist draws. The picture elements depicted on the canvas do not seem to heed the drawing rules as Tisna Sanjaya did. Except for the connotative figure of Suharto who was placed in the middle, Heri Dono seemed to put other figures and objects carelessly. The figures and objects are also positioned equally on the surface (flat) of the canvas. As a result, the canvas appears to be full. The positioning of the figures and objects seems to disregard space, as if there is nothing hidden behind space. The theory of the structure of space and distance (proxemics) from. Hall (1990), for example, becomes irrelevant there. As a result, when Tisna Sanjaya's graphic work negates time, in his paintings Heri Dono "disregards" space. Disregarding such space by itself also negates time.

So, why is the work still able to identify narratives? The drawing technique of Heri Dono is identical to the way children draw. For children, drawing is telling stories (Tabrani, 2005). In other words, what children are concerned about in drawing is not the picture itself, but the story. As a consequence, the picture is not important, and the important thing is the story as the picture becomes just a mere media function. This method is not only demonstrated by children in Indonesia, but also in various countries in the world. Wilson and Wilson (1987) for example, explain how the creativity of Egyptian and Japanese children in Egypt and Japan in drawing is identical with that of storytelling.

The next artist who showed the power of narration in his works was Dede Eri Supria. Some of the titles of Dede Eri Supria's works that can be cited as examples here include: "Ballad of a Puller Cart", "Ballad Pillow", "Ballad of Two Pedicab", "The Story of Urban People and Portraits of Big Cities", "People in Outdoors, "and" Horsemen from America ". It appears that the titles are very specific in identifying themselves as stories. "Ballad" diction as the title of the title, for example, is a term in the literary world which means a moving story or a sad story of a human being that is often expressed in the form of song lyrics or poetry. Kamus Besar Bahasa Indonesia/ Indonesian Dictionary (KBBI) defines ballads as simple 
poems that tell a moving folk tale, sometimes in the form of songs, sometimes dialogues (KBBI, 2003). Following is an analysis of one example of a work whose title identifies such a story, namely "Ballad of a Puller Cart" (figure 5).

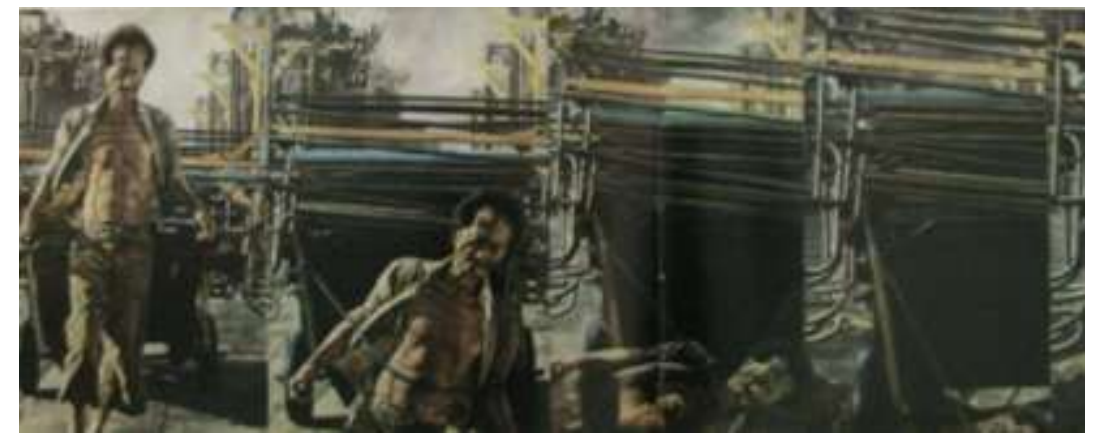

Figure 5. Dede Eri Supria, Balada a Carter, 1983, $121 \mathrm{~cm} \times 385 \mathrm{~cm}, 3$ parts. Source: Dermawan T, (1999)

As shown in the picture above, there are three figures of thin men and in tattered clothes pulling a cart. The first male is shown fully from head to foot in an upright body position. As for the second male, half of his body is shown in an oblique position to the right. As for the third man, only the head is visible and he seems to have fallen to the ground. His hand does not appear to be pulling the cart, but rather makes the handle of the cart as a tool that is held so that he does not fall. On the right side of this scene, there is a wagon without towing.

Analyzing by tracing (reading) the picture from left to right as a visual sign unit on the syntagmatic axis, in the painting there are actually not three male figures, but only one person. In other words, the three male figures painted are the same figures or all three are the same figures, that is, a carter as also made explicit through its title.

If so, the painting is narrating three scenes (plus one scene without a character) that contains events that happened to the carter. Compared with the paradigmatic axis, the scene of four events with a series of visual sign units forms an association about the life of a poor and constantly poor carter. The life history of a cart wagon is a story of misery, helplessness, and ultimately defeat or death (in the fourth scene which appears to be only the cart).

In paintings, the narrative of life is so explicit. Dede Eri Supria is like making a comic without verbal text by uniting four scenes in one panel (one canvas). There, Dede Eri Supria's painting gives the impression of motion, which, in a semiotic sense, sends a connotation message about the use of time. In contrast to Tisna Sanjaya who negates time and Heri Dono who negates time and space in their work, Dede Eri Supria presents both. As a result, Dede Eri Supria's work has more complete requirements as a narrative visual art work than Tisna Sanjaya and Heri Dono.

The way Dede Eri Supria draws in such a way, in some ways, overlaps with how Agus Suwage draws, the last artist that we used as a case example in this article. Consider one of Agus Suwage's works entitled "Devil" below (figure 6):

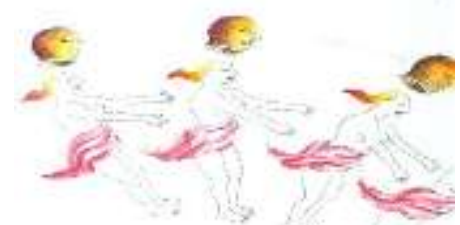

Figure 6. Agus Suwage: Devil Source: Author (2008:181) 
Seen in the picture are four figures - which, if referred to the title of course is a ghost or demonic figure - in a sequential position starting from rising from their backs, standing up, then bending down like they will face down. From another perspective, the sequence of positions can also be seen as a motion of a body that rotates in a circle and moves in a clockwise motion. Looking into more detail, the four figures are drawn exactly the same and the distance from each other is also almost the same. Based on this, the four figures can be read as one figure, as is the figure on the tow cart in Dede Eri Supriya's work. Thus, Agus Suwage's paintings also identify the use of time and space. The motion of one figure in four such scenes identifies an event. So, this work is narrative.

However, besides the similarities, the way Agus Suwage draws also has significant differences, both with Dede Eri Supria and with Tisna Sanjaya and Heri Dono. The first difference is that Agus Suwage's works, almost entirely, are works that do not display a lot of figures or objects. To express the story's events, as in the painting above, Agus Suwage simply combines one figure into several figures in the framework of building associations or connotations of moving signs. This is different from Tisna Sanjaya, Heri Dono, and Dede Eri Supria whose pictures look crowded or are filled with many picture elements combined. This also negates Jim Supangkat's opinion about the crowd as the main characteristic of the narrative visual art. Second, on the paradigmatic axis, the exploration of a few elements of the image into a narrative gives rise to philosophical associations. In other words, the stories visualized by Agus Suwage tend to be stories that have implications for contemplation, for contemplation about human life. This is different from Tisna Sanjaya and Heri Dono whose works tend to be based on culture and politics and Dede Eri Supria who tend to visualize the narratives of human life in social contexts. Third, the way Agus Suwage gives the title of his work is also different from Tisna Sanjaya, Heri Dono, and Dede Eri Supria. The titles of Agus Suwage's work do not identify the story, but tend to be naming. Some examples can be called, among others, "Water, Fire, and Clouds", "Molimo", "Super Chimp", and "Iconofasismo". We say these titles name the story because almost all of the visual forms of his work are narrative.

We have then analyzed a number of works of art from four artists who are considered to represent the tendency of visual art models in Indonesian art. From this analysis we can identify several characteristics of narrative works, which in the title of this article we refer to as narrative patterns in Indonesian art. The narrative pattern can be formulated as follows:

1. Narrative of fine art is a work in which there are interrelated visual sign units forming various associations and connotations about events in human life that can be based on cultural, political, social, and philosophical events;

2. Visually, on the syntagmatic axis, narrative of fine art is a combination of visual elements that identifies events, figures and characterizations, space, and time although not all of these elements must always be present simultaneously. Things that absolutely must be present as a narrative requirement are events and characters. This minimum requirement also explains that narrative art does not necessarily mean a lively work or exploiting various elements of the image.

3. Narration in fine art is different from narration in literary works. If the narrative of a literary work is intact from $\mathrm{A}$ to $\mathrm{Z}$ in a flow interval, the narration in a fine art is representative of the whole. That is, a scene visualized in a work of art, on the paradigmatic axis can lead to an association of a complete and comprehensive narrative that occurs in life. This situation also means that if the way of narrating in literary works is a way of describing the basic ideas (themes), in narrative visual works is the way how the whole story in life is compressed on a visual display on canvas.

4. As a visual text, narration in fine art is, of course, is visual narrative. In visual narrative patterns, visual text stimulates narrative associations and connotations. Thus, the 
narrative itself is complete in the mind of the appreciator. Therefore, Author (2008) called it a symbolic narrative. Meanwhile, Chadwick (1985), when describing the narrative of figurative painting in northern California, called it a narrative image. Here we want to define it as a narrative of semiosis, that is, a narrative constructed by a combination of semiotic sign units in a syntagmatic structure and related relationships to construct meaning associations on the paradigmatic axis.

It is important to stress once again that such a pattern can be said to be the general pattern of Indonesian fine art in various eras. Author's research (2008) shows that the narrative characteristics of Tisna Sanjaya's works, for example, can be traced through the narrative characteristics of traditional art. The similarities of Heri Dono's works can even be traced through prehistoric cave paintings in addition to the wayang in the era of tradition. Finally, the narrative structure by Dede Eri Supria and Agus Suwage has a relationship with early modern era art in Indonesia. Based on this, Author (2017) explained that narrative becomes a kind of DNA (Deoxyribo Nucleic Acid), which is a kind of biomolecule that stores and becomes the genetic instructions of each organism. Author wrote:

"Narrative becomes" the locus of creativity "in the creation of visual works. This is what I mean by the title that narrative becomes DNA (Deoxyribo Nucleic Acid) of Indonesian art. As DNA, the narrative becomes a "cell" that characterizes various aspects, both in the form of surface structure and content (deep structure). As DNA, the narrative becomes a kind of genetic factor that constantly emerges, whether we realized it or not ".

\section{Conclusion}

The study of the structure of works of fine art that have been carried out above proves that works of fine art, in this case Indonesian fine art, have a dominant character as a narrative work of art. The character of the story arises as an expression rooted in the culture of society, that is, people who have a very strong tradition of storytelling. Thus, narrative in Indonesian fine art can be said to be a representation of the collective expression of the community.

We believe that the narrative pattern that has been formulated as a study finding is very important as a source of reference in identifying and understanding works of fine art that are considered to have narrative tendencies. With this pattern, narrative of works of fine art are not merely identified as works that seem crowded or works that have many objects and picture elements in them. Instead, the study above shows that even with one or two picture elements, a work of fine art can be called narrative. The important thing is not the few or many elements of the image, but how the combination within the syntagmatic axis is able to cause narrative associations on the paradigmatic axis. In narrative works, the sign unit that is present as a result of the artist's denote technique must be able to construct connotative signs that become a stimulus to create narrative messages. In other words, connotative visual sign units must be condensing story events in the real life of the society in which the work was created and appreciated. Narrative of fine art is a metaphor "some that represent the whole (pars pro toto), not vice versa, that is, the whole represents a part (totem pro parte). Based on this, the narrative pattern that has been found is not only applicable and useful for identifying Indonesian fine art works, but can also be used to identify signs of storytelling in works of fine art with different social and cultural backgrounds of other people or nations. Therefore, these findings have become a significant contribution to the world of fine art, both at the theoretical and practical level. We recommend that further researchers undertake a broader and deeper study related to this topic by making the findings above as a preliminary reference. However, each work with a different socio-cultural background requires a different character marker.. 


\section{References}

Author. 2008. Narasi Simbolik Seni Rupa Kontemporer Indonesia. Yogyakarta: IsaacBook.

Author. 2015. Tradisi Lisan Tersier HU Kompas.

Author. 2017. Narasi sebagai dna seni rupa Indonesia. In: Seminar Nasional Pascasarjana Institut Seni Indonesia (ISI) Bali. Unpublished.

Barthes, R. 1985. Elements of Semiology Translated from French by Annette Lavers and Colin Smith. New York: Hill and Wang.

Basirizadeh, F.S. et. al. (2020). Postmodernism Aspects in Lens of Baudrillard Theory in the novels DeLillo's white noise and Atwood `s Handmaid's tale. Britain International of Linguistics, Arts and Education (BIoLAE) Journal Vol. 2 (3): 713-723.

Belting, H. 1985. The new role of narrative in public painting of the trecento: "Historia" and Allegory". Studies in the History of Art 16: 151-168, Symposium Papers IV: Pictorial Narrative in Antiquity and the Middle Ages

Danesi, M. 2004. Messages, Signs, And Meanings: A Basic Textbook in Semiotics and Communication Theory. Toronto: Canadian Scholars' Press.Inc.

Dermawan, TA. 1999. Dede: Elegi Kota Besar. Jakarta: Yayasan Seni Rupa AIA

Chadwick, W. 1985. Narrative imagism and the figurative tradition in northern california painting Art Journal, 45(4): 309-314

Genette, G. 1987 Paratext, Thresholds of Interpretation. UK: Cambridge University Press.

Genette, G. 1995. Narrative Discourse. USA: Cornell University Press.

Green, JR. 1999. Tragedy and the spectacle of the mind: Messenger speeches, actors, narrative, and audience imagination in fourth-century bce vase-painting. Studies in the History of Art, Vol. 56, Symposium Papers XXXIV: The Art of Ancient Spectacle, pp. 36-63. http://www.jstor.org/stable/42622232

Hall, ET. 1990. The Hidden Dimension. New York: Anchor Books.

Iswahyudi. (2020). Towards Remediation of Indonesian New Fine Arts. Britain International of Linguistics, Arts and Education (BIoLAE) Journal Vol. 2 (3): 797-809.

Junus, U. 1981. Mitos dan Komunikasi. Jakarta: Sinar Harapan.

Juvancic, M., \& Verovsek, S. 2018. Narrating and explaining urban stories through inherited visual urban vocabulary. New Media \& Society, 17(1), 781-797. https://doi.org/10.1177/1461444811425222

Ong, W.J. 2004. Orality and Literacy, The Technologizing of The Word. London and New York: Routledge.

Ricoeur, P. 2002. The Interpretation Theory Filsafat Wacana Membelah Makna dalam Anatomi Bahasa translated by Musnur Hery. Yogyakarta: IRCiSOD

Saussure, F.D. 1990. Course in General Linguistics Edited by Charles Bally and Albert Sechehaye with the collaboration of Albert Riedlinger. Translated and annotated by Roy Harris. London: Duckworth.

Supangkat, J. 1996. Indonesian Modern Art and Beyond. Jakarta: Yayasan Seni Rupa Indonesia.

Wilson, B. and Wilson, M. 1987. Pictorial composition and narrative structure: Themes and the creation of meaning in the drawings of egyptian and japanese children. Visual Arts Research,13 (2):10-21.

Tabrani, P. 2005. Bahasa Rupa. Bandung: Kelir.

Teeuw, A. 1984. Sastra dan Ilmu Sastra. Jakarta: Gramedia.

Zoest, A.V. 1992. Interpretasi dan Semiotika. In Serba-Serbi Semiotika. Jakarta: Gramedia. PP: $1-25$. 